\title{
PENGELOLAAN WAKAF PONDOK PESANTREN AL-HIKMAH SIRAMPOG KABUPATEN BREBES
}

\author{
Edi Setiawan \\ UIN Sunan Gunung Jati Cirebon \\ edysetyawano@yaboo.com
}

\begin{abstract}
Abstrak
The purpose of this study is to reveal the waqf management practices in Al-Hikmah Islamic Boarding School and contribution to education and community empowerment, and uncover the factors supporting and managing endowments in the foundation. This research used qualitative research methods with case study management approach. The results of this study showed that Endowments foundation is managed in synergy with the management of education. Management practices applied this foundation is still traditional. Utilization endowments for community empowerment is realized through activities which can be grouped into four areas: Economics, Department of Structure, and Education and Religious Affairs.
\end{abstract}

Keywords: Endowments, Empowerment, Management, Education, Community, Charismatic Leadership

\begin{abstract}
Abstrak
Tujuan dari penelitian ini adalab untuk mengetabui praktek manajemen wakaf di Pondok Pesantren Al-Hikmah dan kontribusi wakaf terhadap pendidikan dan pemberdayaan masyarakat, serta mengungkap faktor pendukung dan pengelolaan mengelola wakaf di yayasan. Penelitian ini menggunakan metode penelitian kualitatif dengan pendekatan manajemen studi kasus. Hasil penelitian ini menunjukkan bahwa Wakaf yayasan Pondok Pesantren Al-Hikmah dikelola secara sinergis dengan pengelolaan pendidikan. YPPP Al-Hikmah, dalam pengelolaan wakafnya masih bersifat tradisional. Pemanfaatan wakaf untuk pemberdayaan masyarakat di YPPP Al-Hikmah Sirampog Kabupaten Brebes direalisasikan melalui kegiatan-kegiatan yang dapat dikelompokkan menjadi empat bidang, yaitu bidang ekonomi, bidang kesehatan, bidang sarana, bidang pendidikan dan keagamaan
\end{abstract}

Kata Kunci: Wakaf, Pemberdayaan, Manajemen, Pendidikan, Kepemimpinan Karismatik

Permalink/DOI: http://dx.doi.org/10.18326/infsl3.v10i2.495-516 


\section{Pendahuluan}

Pesantren, sebagai suatu subkultur, lahir dan berkembang seiring dengan derap langkah perubahan yang ada dalam masyarakat global, perubahan-perubahan yang terus bergulir itu cepat atau lambat, pasti akan mengimbas pada komunitas pesantren sebagai bagian dari masyarakat dunia. Karenanya tidaklah berlebihan jika (Mahfudz 1994: 355) menyebutkan ada dua peranan besar yang dimiliki pesantren, sehingga pesantren bisa tetap survive hingga sekarang ini, yakni pesantren sebagai lembaga pendidikan dan pesantren sebagai lembaga sosial keagamaan

Mencari peranan pesantren dalam pemberdayaan masyarakat, bukanlah telaah yang mengada-ada, diharapkan dengan kemampuan yang sekarang dimiliki, pesantren sebenarnya mempunyai potensi yang cukup besar untuk bisa menjadi basis bagi pemberdayaan masyarakat serta pesantren sebagai suatu lembaga yang tumbuh dari dan dalam masyarakat diharapkan dapat melayani berbagai macam kebutuhan masyarakat (kebutuhan pendidikan atau sosial keagamaan) (Billah, 1986: 290).

Di masa-masa awal penyiaran Islam, kebutuhan masjid untuk menjalankan aktivitas ritual dan dakwah membuat pemberian tanah wakaf untuk mendirikan masjid menjadi tradisi yang lazim dan meluas. Seiring dengan perkembangan sosial masyarakat Islam dari waktu ke waktu, praktik perwakafan mengalami kemajuan setahap demi setahap. Tradisi wakaf untuk tempat ibadah tetap bertahan, tetapi mulai muncul juga wakaf untuk pendirian pesantren dan madrasah. Dalam periode berikutnya, corak pemanfaatan wakaf terus berkembang, sehingga mencakup pelayanan sosial dan kesehatan, seperti untuk pendirian klinik dan panti asuhan (Najib dkk, 2006: 71)

Dalam konteks sejarah umat Islam, penggunaan wakaf untuk pendidikan dan kesejahteraan masyarakat bukanlah hal baru. AlAzhar yang berdiri sejak abad ke-10 M merupakan lembaga terdepan yang kemudian ditiru oleh lembaga-lembaga pendidikan besar di Amerika Serikat dan Inggris. Sejak berdirinya, Al-Azhar menetapkan diri sebagai lembaga pendidikan swasta yang menggantungkan dirinya pada aset-aset wakaf. Salah satu keunggulan Universitas Al- 
Azhar di Kairo terletak pada wakafnya yang amat besar. Bukan hanya wakaf tanah, gedung dan lahan pertanian, tetapi juga wakaf uang. Dengan wakaf yang amat besar itu, Al-Azhar mampu membiayai operasional pendidikannya selama berabad-abad tanpa bergantung pada pemerintah maupun pembayaran siswa dan mahasiswanya. Al-Azhar bahkan mampu memberikan beasiswa kepada ribuan mahasiswa dari seluruh penjuru dunia selama berabad-abad (Muhyar, 2009: 35).

Secara historis, wakaf telah memainkan peranan penting dalam perkembangan Islam. Rasulullah selalu menganjurkan agar umatnya gemar beramal, di antara amal yang dianjurkan itu adalah menyebarkan ilmu, menyelenggarakan pendidikan, membuat karya tulis, membangun sarana ibadah, rumah tempat singgah musafir, penyediaan air bersih dan lain-lain (Al-Mana>wi>, 1972: 437-438).

Dengan demikian wakaf jika dikelola dengan profesional maka sangat membantu pembangunan, baik di bidang ekonomi, sosial budaya, agama, politik maupun pertahanan keamanan. Pada bidang ekonomi, wakaf memegang peranan dalam menjaga keseimbangan kondisi kehidupan masyarakat karena dapat memenuhi kebutuhan vital mereka.

Berkembang tidaknya wakaf sangat bergantung pada bagaimana nazhir mengelola wakaf, karena sistem wakaf dalam dunia Islam mengalami perkembangan seiring dengan arus perkembangan zaman. Sistem wakaf tidak terbatas dan tidak statis, berbagai model administrasi baru secara terus menerus dikembangkan sehingga meningkatkan efisiensi dan hasil maksimal. Syarbi>ni>y (1997:510) menegaskan bahwa nazhir berkewajiban mengembangkan, memajukan, meyewakan harta wakaf, dan mencari keuntungan agar bisa mendistribusikan hasilnya.

Madrasah dan pondok pesantren sebagai lembaga pendidikan Islam dan dakwah, memiliki peran, fungsi dan kontribusi dalam mewujudkan masyarakat madani Indonesia. Pesantren sebagai lembaga pendidikan keagamaan yang hidup sepanjang masa harus selalu mengembangkan dan meningkatkan peran dirinya demi kepentingan masyarakat. Pemikiran ini relevan dengan pesan yang disampaikan oleh sebuah hadis bahwa sebaik-baik manusia adalah 
yang paling mempu memberikan manfaat kepada orang banyak atau masyarakat (Zubaedi, 2007:205). Pondok pesantren sebagai lembaga pendidikan tetap konsisten melakukan perannya sebagai pusat pendalaman ilmu-ilmu agama dan pusat dakwah Islam serta ikut berperan aktif dalam mencerdaskan bangsa telah diakui oleh masyarakat, dibuktikan dengan kesuksesannya dalam melahirkan para tokoh agama, pejuang bangsa serta tokoh masyarakat, baik di masa sebelum kemerdekaan, setelah kemerdekaan maupun di zaman sekarang. Ini merupakan bukti riil bahwa pesantren telah banyak memberikan kontribusi dalam membangun bangsa Indonesia.

Fokus utama penelitian ini diarahkan untuk mengungkap mengapa pengelolaan wakaf di Yayasan Pendidikan Pondok Pesantren Al-Hikmah Sirampog Kabupaten Brebes bisa bertahan dan berkembang hingga umurnya yang ke-103 tahun (1911-2014). Namun di sisi lain, dibalik pengelolaan wakaf yang bisa bertahan dan berkembang tersebut, ada masalah yang dihadapi oleh yayasan ini yang harus dicarikan solusinya.

\section{Manajemen}

Dalam pandangan Olum (2004:2), manajemen adalah the art, or science, of achieving goals through people (seni atau ilmu untuk mencapai tujuan melalui orang). Apabila manajer juga bertugas mengawasi, maka manajemen dapat diartikan secara harfiah "melihat dari atas", yaitu memastikan orang melakukan apa yang seharusnya mereka lakukan. Taylor (1919:122-125) mengartikan manajemen dengan seperangkat mekanisme atau teknik guna meningkatkan efesiensi dan keefektifan organisasi. Titik berat dari pemikiran Taylor ialah pada peningkatan efesiensi dan keefektifan pekerja tingkat bawah dengan cara meningkatkan produktivitas dan memperbesar bidang produksi. Fungsi manajemen menurut Taylor ialah planning (perencanaan), directing (mengarahkan), dan organizing of work (pengorganisasian pekerjaan).

Manajemen juga diartikan suatu proses yang terdiri dari planning (perencanaan), organizing (pengorganisasian), staffing (susunan kepegawaian), motivating (mengarahkan), dan 
controlling (pengendalian) yang dilakukan untuk mencapai tujuan yang ditetapkan dengan melibatkan pengetahuan bagaimana melaksanakan fungsi-fungsi utama manajemen dengan menggunakan orang-orang dan sumber daya (Terry, 2000:9-10); (Havinal, 2009:2-3); (LPU, 2011:2). Sementara itu, Fayol berpendapat bahwa manajemen adalah serangkaian proses yang terdiri dari fungsi-fungsi planning (perencanaan), organizing (pengorganisasian), commanding (kepemimpinan), dan controlling (pengendalian), yang sering disingkat dengan POC3 (Hasibuan, 2014: 13, 38).

Dengan demikian, manajemen merupakan proses yang dilakukan melalui perencanaan, pengorganisasian, kepemimpinan, dan pengawasan dengan mengerahkan sumber daya organisasi dalam rangka mencapai tujuan yang ditetapkan. Seorang pimpinan harus mempunyai keahlian atau kemampuan dalam hal manajemen. Secara terperinci dalam diklasifikasikan dalam kemampuan atau keahlian sebagai berikut: perencanaan (planning), pengorganisasian (organizing), penggerakan (actuating), dan pengawasan (controlling).

Manajamen wakaf diperlukan sebagai upaya agar kegiatan pengelolaan wakaf dapat berjalan secara efektif dan efisien. Agar manajemen wakaf yang dilakukan mengarah kepada kegiatan pengelolaan yang efektif dan efisien, maka manajemen wakaf perlu dijelaskan berdasarkan fungsi-fungsi manajemen secara umum. Fungsi manajemen merupakan sejumlah kegiatan yang meliputi berbagai jenis pekerjaan yang dapat digolongkan dalam satu kelompok sehingga membentuk satu kesatuan administratif. Fungsi manajemen itu dapat dilihat dari pengertian manajemen menurut Frederich Winslow Taylor, Henry Fayol dan George R. Terry sebagaimana telah dikemukakan di atas.

\section{Pemberdayaan}

Terminologi pemberdayaan diambil dari khazanah bahasa Inggris sebagi bentuk aktif dari kata daya atau kuasa (power) yakni empowerment. Power adalah tenaga, kekuasaan, kemauan, kemampuan, kesanggupan, kesadaran, pemahaman, perlindungan 
dan kesiapan yang berkaitan dengan hak dan kewajiban, baik personal, kelompok, komunitas maupun organisasiyang dibingkai kelembagaan dalam berbagai lingkup sosial. Makna nyata (overt meaning) maupun makna abstrak (covert meaning) dari power sangat nyata mewarnai konsep dan makna pemberdayaan. Pemberdayaan pada hakekatnya adalah penguatan kemampuan, kemauan, keterampilan, keberanian, daya penafsiran, dan keterbatasanketerbatasan yang dimiliki oleh masyarakat atau kelompok yang berada di bawah dominasi penguasa (Setiawan, 2012:274-275).

Sedangkan masyarakat menurut Soekanto (2014:130-131) adalah setiap kelompok manusia yang hidup dan bekerja sama cukup lama sehingga mereka dapat mengatur diri mereka dan menganggap diri mereka sebagai satu kesatuan sosial dengan batas-batas yang dirumuskan dengan jelas. Pemberdayaan masyarakat (community development/empowerment) adalah suatu usaha pemberian atau peningkatan "kekuasaan" (power) kepada masyarakat yang lemah atau tidak beruntung (disadvantaged) melalui perubahan struktur sosial, di mana rakyat (masyarakat) mampu menguasai (berkuasa atas) kehidupannya, sehingga harkat dan martabat kehidupan masyarakat dapat berkembang ke arah yang lebih baik. Menurut Soetomo (2011:69), Posisi masyarakat yang marginal dan powerless dibuat menjadi lebih berdaya. Dengan demikian pendekatan yang digunakan disebut sebagai pemberdayaan masyarakat.

Konsep pemberdayaan dapat dilihat dari tiga sisi. Pertama, enabling, pemberdayaan dengan menciptakan suasana atau iklim yang berkembang. Kedua, empowering, pemberdayaan untuk memperkuat potensi ekonomi atau daya yang dimiliki masyarakat dalam rangka memperkuat potensi ini, upaya yang amat pokok adalah peningkatan taraf pendidikan, derajat kesehatan, serta akses terhadap sumber-sumber kemajuan ekonomi, seperti modal, teknologi, informasi, lapangan kerja dan pasar. Ketiga, pemberdayaan melalui pengembangan ekonomi rakyat dengan cara melindungi dan mencegah terjadinya persaingan yang tidak seimbang, serta menciptakan kebersamaan dan kemitraan antara yang sudah maju dengan yang belum berkembang (Sawai, dkk, 2005:17-19). 


\section{Tujuan Pemberdayaan}

Tujuan dari pemberdayaan adalah memperkuat kekuasaan masyarakat, khususnya kelompok lemah yang memiliki ketidakberdayaan, baik karena kondisi internal (misalnya persepsi mereka sendiri), maupun karena kondisi eksternal (misalnya ditindas oleh struktur sosial yang tidak adil) (Suharto, 2010:60).

Dengan kata lain, pemberdayaan menunjuk pada keadaan atau hasil yang ingin dicapai oleh sebuah perubahan sosial, yaitu masyarakat yang berdaya, memiliki kekuasaan atau mempunyai pengetahuan dan kemampuan dalam memenuhi kebutuhan hidupnya baik yang bersifat fisik, ekonomi, maupun sosial seperti memiliki kepercayaan diri, mampu menyampaikan aspirasi, mempunyai mata pencaharian, berpartisipasi dalam kegiatan sosial, dan mandiri dalam melaksanakan tugas-tugas kehidupannya.

\section{Proses Pemberdayaan dan Strategi Pemberdayaan}

Proses atau pendekatan pemberdayaani dapat dicapai dengan melakukan pendekatan pemberdayaan yang dapat disingkat menjadi 5P yaitu: a) Pemungkinan; b) Penguatan; c) Perlindungan; d) Penyokongan; e) Pemeliharaan (Suharto, 2010: 67-68). Secara umum ada 4 (empat) strategi pemberdayaan masyarakat, yaitu: a) The Growth Strategy; b) The Welfare Strategy; c) The Responsitive Strategy; d) The Integrated or Holistic Strategy (Aziz, dkk, 2009:8-9). Pemberdayaan memiliki 3 (tiga) kontek wilayah yang berbeda dan sangat mempengaruhi kehidupan manusia. Ketiga konteks pemberdayaan tersebut adalah pemberdayaan ruhaniyah, pemberdayaan intelektual dan pemberdayaan ekonomi (Mahendrawati, 2001:59).

Pemberdayaan masyarakat melalui wakaf bisa direalisasikan lewat usaha-memberikan modal atau bantuan yang dikategorikan ke dalam tiga jenis yaitu bidang ekonomi, bidang pendidikan dan bidang kesehatan. Dalam bidang ekonomi, yaitu pemberian bantuan usaha, sedangkan dalam bidang pendidikan, yaitu pemberian beasiswa dan dalam bidang kesehatan yaitu dengan memberikan bantuan pengobatan. 


\section{Kepemimpinan Karismatik}

Istilah karisma berasal dari kata Yunani yang berarti karunia (gift), anugerah atau pemberian. Karis berarti menyukai, merujuk kepada kepribadian seseorang yang memiliki kepribadian menarik ataupun memiliki daya pikat, mempunyai penampilan menarik atau mampu berkomunikasi, sehingga banyak orang yang menyukainya (Alfian, 2009:140). Artinya orang yang memiliki karisma berarti orang yang memiliki kelebihan, perbedaan dan keistimewaan dari pada yang lain.

Kepemimpinan karismatik mengidentifikasi daya tarik kualitas kepribadian yang dimiliki oleh seseorang sebagai pribadi. Penampilan seseorang dianggap karismatik dapat diketahui dari ciriciri fisiknya, misalnya tekun, berpandangan tajam, tegas, pemberani, supel penuh percaya diri, berpengaruh besar, semuanya menjelma dalam kata, ide dan tindakan (Horikoshi, 1987:213). Sementara sederet kepribadian lainnya yang merupakan sifat-sifat karismatik, misalnya matanya yang bercahaya, suaranya yang kuat, dagunya yang menonjol, atau tanda-tanda lain (Sukamto, 1999:25).

Konsep karisma dianggap Weber (1946:52) sebagai konsepsi penyeimbang birokrasi. Karisma yang makna harfiahnya "karunia istimewa" digunakan Max Weber untuk mengarakterisasi pemimpin yang mengangkat diri sendiri dan diikuti oleh mereka yang dirundung kesulitan berat dan butuh mengikuti pemimpin karena mereka mempercayainya punya keutamaan luar biasa. Para pendiri agama dunia dan para nabi maupun para pahlawan militer dan politik adalah model awal pemimpin karismatik. Mukjizat dan wahyu, prestasi keberanian heroik dan keberhasilan mencengangkan adalah ciri khas keutamaan mereka. Kegagalan adalah kehancuran mereka. Karena itu,para pahlawan dan nabi-nabi karismatik dipandang sebagai kekuatan revolusioner sejati dalam sejarah.

Birokrasi dan institusi-institusi lain, utamanya institusi rumah tangga, dipandang sebagai rutinitas kehidupan sehari-hari; karisma berlawanan dengan semua rutinitas institusional, rutinitas tradisi dan rutinitas yang tunduk pada manajemen rasional. Ketika digunakan dalam cara teknis yang ketat, konsep karisma terbebas dari segala evaluasi, karena secara faktual orang-orang mematuhi mereka karena keyakinan pada kualitas personal mereka yang luar biasa (Weber, 1946: 52). 
Menurut Max Weber kepemimpian bisa muncul tatkala masyarakat sedang mengalami krisis dan ketidakpastian. seorang pemimpin karisma muncul dengan sebuah visi radikal yang menawarkan sebuah solusi untuk krisis itu, pemimpin menarik pengikut yang percaya pada visi itu, mereka mengalami beberapa keberhasilan yang membuat visi itu terlihat dapat dicapai, dan para pengikut dapat mempercayai bahwa pemimpin itu sebagai orang yang luar biasa (Weber, 1947:249).

\section{Metode Penelitian}

\section{Jenis dan Pendekatan Penelitian}

Jenis penelitian ini adalah penelitian lapangan (field research). Penelitian ini menggunakan metode penelitian kualitatif dengan studi kasus dan menggunakan pendekatan manajemen. Melalui pendekatan ini, Peneliti berusaha untuk mengkaji dan mengevaluasi pengelolaan wakaf oleh yayasan tersebut terutama berkaitan dengan pengelolaan dan penerapan fungsi-fungsi manajemen.

\section{Teknik Pengumpulan Data dan Analisis Data}

Dalam rangka mengumpulkan data dan memilah datadata penelitian, peneliti menggunakan beberapa metode yakni a) Observasi, ; b) Wawancara, c) Dokumentasi. Teknik analisis data yang digunakan dalam penelitian ini adalah analisis data kualitatif

\section{Pengelolaan Wakaf di Pon-Pes Al-Hikmah Sirampog Kabupaten Brebes}

Yayasan Pendidikan Pondok Pesantren (YPPP) Al-Hikmah Sirampog Kabupaten Brebes mempunyai aset tanah wakaf yang sangat luas ( $\pm 12,8$ hektare) dalam pengelolaannya dibutuhkan profesionalisme untuk pengembangan aset wakaf tersebut. Wakaf YPPP Al-Hikmah Sirampog Kabupaten Brebes dikelola secara sinergis dengan pengelolaan pendidikan. Harta wakaf dimaksimalkan fungsi dan hasilnya untuk mendukung kegiatan pendidikan di YPPP AlHikmah. Hasil wakaf digunakan untuk menopang operasional 
pendidikan, baik untuk menyediakan sarana prasarana maupun biaya operasional unit-unit pendidikan. Di sisi lain YPPP Al-Hikmah juga berusaha menggunakan aset wakaf untuk investasi yang bersifat profit oriented (mencari laba).

Pengelolaan wakaf sejak awal dipisahkan dari harta para nazhir dan pengurusnya. Menurut KH. Sholahudin, keturunan pendiri pesantren meskipun tinggal di area pesantren, namun rumah mereka dibangun di atas tanah milik pribadi, bukan tanah wakaf. Semasa hidupnya KH. Masruri Abdul Mughni sudah menyediakan lahan-lahan khusus untuk ditempati sebagai tempat tinggal di kemudian hari, tanpa mengganggu tanah wakaf yang ada.

Pimpinan YPPP Al-Hikmah yang bertindak selaku ketua nazhir wakaf dibantu oleh para pengelola pesantren. Dalam kepemimpinannya telah banyak mengupayakan pengembangan dan pemberdayaan harta wakaf yang dimiliki pesantren.

Luas lahan wakaf yang dimiliki YPPP Al-Hikmah $\pm 12,8$ hektare tidak seluruhnya digunakan sebagai sarana pendidikan saja. Lahan yang dimiliki masih sangat luas, sehingga lahan yang masih tersisa diberdayakan untuk menunjang operasional pesantren. Pendiri Pesantren Al-Hikmah semenjak awalnya selalu berupaya untuk mencari sumber-sumber dana agar lembaga pendidikan tetap survive. Nazhir wakaf YPPP Al-Hikmah sebagai lembaga pengelola membuka berbagai upaya yang secara garis besarnya dapat dibagi dua macam, yaitu mengolah lahan pertanian dan membuka unitunit usaha yang berhasil guna.

\section{Tabel 3}

\section{Penggunaan Tanah Wakaf YPPP Al-Hikmah}

\begin{tabular}{lll}
\hline No & Peruntukan Wakaf & Luas $\left(\mathbf{m}^{\mathbf{2}}\right)$ \\
\hline 1 & Sarana pendidikan & $\pm 56.580 \mathrm{~m}^{2}$ \\
2 & Sawah & $\pm 68.014 \mathrm{~m}^{2}$ \\
3 & Pekarangan & $\pm 3.3954 \mathrm{~m}^{2}$ \\
\hline
\end{tabular}




\section{Pemberdayaan Pertanian}

Yayasan Pendidikan Pondok Pesantren Al-Hikmah Sirampog Kabupaten Brebes memiliki tanah-tanah wakaf baik tanah kering maupun tanah basah. Hingga 2014 tanah wakaf berjumlah $\pm 12,8$ ha, Tanah-tanah tersebut telah dikelola sedemikian rupa oleh Yayasan Pendidikan Pondok Pesantren Al-Hikmah Sirampog Kabupaten Brebes.

Sebagaimana telah dilaporkan bahwa YPPP Al-Hikmah memiliki tanah wakaf yang sangat luas, terdiri dari tanah-tanah wakaf yang berasal dari para pewakaf, termasuk dari para pendiri pondok seluas $10,7 \mathrm{ha}$, dari hasil pembelian seluas \pm 2 hektare hingga seluruhnya $\pm 12,8$ ha. Dilihat dari jenisnya, wakaf Pesantren Al-Hikmah terdiri dari tanah basah (tanah sawah) dan tanah kering (darat). Tanah-tanah sawah dikelola oleh para petani penggarap dengan pola muza>ra'ah atau mukha>barah. Menurut data tahun 2013 menunjukkan bahwa tanah sawah yang digarap oleh para petani penggarap luasnya mencapai 6,8 ha.

Adapun mengenai pengelolaan tanah darat, selain digunakan untuk bangunan fisik pondok dan sarana-sarana pendidikan digunakan untuk pengembangan usaha pertokoan, percetakan, perkebunan, tata busana, biogas, perikanan, pengelasan dan peternakan. Pengembangan usaha bidang perkebunan masih bersifat tradisional, menanam tanaman holtikultura, sayur-mayur dan rempah-rempah sekedar untuk memenuhi kebutuhan pondok. Demikian pula pengembangan bidang peternakan belum intensif. Peternakan kambing, dan penggemukan sapi belum diolah secara intensif yang hasilnya dapat dipasarkan ke luar. Sementara sapi potong dan kambing pengelolaannya ditangani langsung oleh pesantren, karena Usaha Penyembelihan sapi atau kambing baru dirintis. Hasil pemotongan hewan dagingnya dikirimkan ke dapur-dapur santri dan ustaz serta keluarga pondok dalam rangka memenuhi kebutuhan gizi di lingkungan pondok. 


\section{Pemberdayaan Unit Usaha}

Di antara syarat penting bagi sebuah lembaga pendidikan untuk dapat bertahan bidup dan berkembang adalah memiliki sumber dana sendiri. Sejak berdirinya, Pesantren Al-Hikmah Sirampog Kabupaten Brebes telah memperhatikan masalah ini dengan sungguh-sungguh. Untuk mencukupi segala sarana dan prasarana serta berbagai kebutuhan lain demi berlangsungnya proses pendidikan dan pengajaran di pondok, didirikanlah berbagai unit usaha baik yang ditangani santri-santri senior, maupun yang ditangani oleh guru atau ustaz. Bermacam-macam usaha telah dilakukan untuk memenuhi maksud ini, antara lain dengan membuka bidang-bidang usaha yang dapat menjadi sumber dana pondok, berupa usaha Pusat Pendidikan dan Pelatihan Pengembangan Kewirausahaan Agribisnis Pertanian, perternakan, Agribisnis Pertanian, Workshop Komputer dan warnet, Tata Busana, Pengelasan, BBAT, Koperasi Malhik 2 (M2Mart), percetakan dan Pusat Kesehatan Santri dan Masyarakat.

Berdasarkan pada penjelasan tersebut di atas, praktik-praktik manajemen yang diterapkan YPPP Al-Hikmah jika dilihat dari tahapan manajemennya yaitu perencanaan, pengorganisasian, pengarahan dan pengawasan, pihak YPPP Al-Hikmah belum sepenuhnya melaksanakan tahapan-tahapan tersebut dengan baik. Hal ini terbukti dari susunan pengurus nazhir yang belum menggambarkan divisi-divisi untuk pengelolaan wakaf secara profesional.

\section{Analisis praktik penerapan fungsi manajemen dalam pengelolaan wakaf}

\section{Perencanaan}

YPPP Al-Hikmah secara praktik telah menempuh salah satu proses perencanaan dan unsur perencanaan yaitu penetapan tujuan. Ini terbukti bahwa yayasan dalam mengelola wakaf telah menetapkan tujuan pengadaan program wakaf, yaitu untuk pengembangan lembaga pendidikan dan pesantren dalam bentuk pembebasan lahan, serta penyediaan sarana dan prasarana pendidikan. Namun tujuan-tujuan tersebut masih secara global dan tidak dirinci dalam bentuk yang spesifik. YPPP Al-Hikmah belum 
sepenuhnya melaksanakan prosedur perencanaan dan unsurnya yang ideal.

Perencanaan ada beberapa macam, yaitu perencanaan fisik (physical planning) dan perencanaan pembiayaan (cost planning atau financial planning). Nazhir wakaf YPPP Al-Hikmah belum merancang perencanaan mengenai hal-hal yang hendak dihasilkan dari wakaf, baik materiil maupun immateriil. Pola yang dilakukan selama ini masih insidental, tergantung kebutuhan yang dihadapi oleh yayasan. Perencanaan pembiayaan wakaf untuk memperoleh sumber keuangan yang diperlukan untuk membiayai planning yang diperlukan juga belum dilakukan. Dana yang diperoleh dari hasil pengelolaan wakaf dikumpulkan oleh bendahara dan setiap saat bisa digunakan jika ada kebutuhan tertentu meskipun tidak terprogram.

Nazhir wakaf Pesantren Al-Hikmah tidak terjadual melakukan kegiatan rapat untuk penyusunan perencanaan. Mereka tidak memprogramkan rapat kerja, rapat bulanan, dan rapat mingguan guna penyusunan rencana program dan memberikan gambarangambaran umum tentang tujuan dan program-program yang ingin dicapai di masa depan. Mereka hanya rapat secara insidental jika dibutuhkan saja, sehingga rancangan program kerja, target dan rencana-rencana yang akan dilakukan tidak ditemukan dalam agenda kegiatan mereka.

\section{Pengorganisasian}

Dalam hal pengorganisasian, YPPP Al-Hikmah telah melaksanakan fungsi ini dengan baik. Hal ini dapat dilihat dari adanya susunan struktur organisasi, susunan pengurus, pendelegasian wewenang dan tanggung jawab yang jelas dan terstruktur yang terdiri dari pembina, ketua, wakil, sekretaris, pengawas, bendahara dan anggota. Hanya saja masih ada beberapa hal yang perlu ditambahkan, seperti divisi-divisi atau seksi-seksi yang bertugas untuk pemberdayaan, rekrutmen wakif baru, seksi usaha dan lain-lain yang menunjang pemberdayaan dan pengembangan wakaf. Dilihat dari struktur organisasinya, struktur nazhir YPPP AlHikmah termasuk organisasi lini yang bercirikan organisasi yang 
masih kecil, jumlah pengurus yang masih sedikit dan spesialisasi yang masih kurang memadai.

Agar berjalan dengan baik, aktivitas pembagian kerja harus memenuhi syarat "the right man on the right place". Dalam sudut kinerja, seharusnya penempatan nazhir disesuaikan dengan bidang dan keahlian masing-masing, syarat ini akan dapat mengupayakan efisiensi kerja yang baik. Ini tidak sesuai dengan apa yang dilakukan oleh YPPP Al-Hikmah dalam penempatan pengurus nazhir yang belum sesuai dengan bidangnya. Penunjukkan nazhir masih didasarkan pada pertimbangan historis, seperti orang tersebut (atau orang tuanya) pernah berjuang atau menjadi saksi hidup dalam pengembangan pesantren atau yang bersangkutan mempunyai sifat amanah. Menurut KH. Sholahudin, seiring dengan perkembangan SDM yang ada, hal tersebut akan dibenahi secara bertahap.

Selain penempatan pengurus yang belum sesuai dengan bidangnya, tugas-tugas mereka pun belum jelas, karena YPPP AlHikmah belum mempunyai job description nazhir yang tertulis sebagai pedoman dalam bekerja.

\section{Penggerakan}

Fungsi penggerakan yang dilakukan oleh YPPP Al-Hikmah yaitu motivasi, komunikasi dan kepemimpinan. Dalam fungsi penggerakan organisasi wakaf di YPPP Al-Hikmah belum dilakukan secara terjadual secara periodik yang tertuang dalam program kerja, padahal jika dilakukan sesuai dengan fungsi penggerakan yang ideal maka kinerja para nazhir akan baik. Mereka akan berusaha untuk mencapai sasaran-sasaran agar sesuai dengan perencanaan manajerial dan usaha-usaha organisasi. Kinerja nazhir pada pengelolaan wakaf hakekatnya sudah baik namun belum maksimal, ini disebabkan karena mereka tidak dimotivasi secara berkala dalam kegiatan yang terencana.

\section{Pengawasan}

Bentuk kontrol nazhir yang dilakukan di YPPP Al-Hikmah meliputi kontrol yang berasal dari diri sendiri yaitu dengan 
mengeman amanah tugas penuh tanggung jawab sebagai sarana untuk mendekatkan diri kepada Allah SWT dan kontrol dari luar diri sendiri

Bentuk kontrol dari luar diri sendiri yang diterapkan oleh lembaga wakaf ini di antaranya: 1) Kontrol Yayasan, Bentuk kontrol yang dilakukan oleh yayasan masih dalam bentuk yang sangat sederhana, seperti mengontrol jumlah aset wakaf, pemasukan dari bagi hasil paroan sawah dan lain-lain secara lisan, karena tradisi lisan di pesantren ini lebih dominan daripada budaya tulis. Kontrol yayasan ini masih kurang maksimal karena tidak mempunyai panduan SOP (Standart Operating Procedure) yang dibuat oleh yayasan. Pihak YPPP Al-Hikmah sendiri lebih banyak memantau penggunaan dananya melalui laporan-laporan secara lisan. 2) Kontrol dari pengawas nazhir, Dalam tatanan kepengurusan lembaga wakaf di YPPP Al-Hikmah, posisi pengawas manajemen tidak begitu banyak berperan. Hal ini terjadi karena aturan main secara tertulisnya belum ada, mereka lebih banyak saling percaya satu sama lainnya. Sehingga kontrol yang mereka lakukan juga masih bersifat insidental dan kondisional. Bentuk kontrol yang dilakukan hanya sekedar arahan dalam bentuk nasehat terhadap nazhir agar kinerja yang mereka lakukan tetap sejalan dengan tujuan asal wakaf. 3) Kontrol ketua nazhir, Pengawasan yang dilakukan oleh ketua nazhir wakaf di YPPP Al-Hikmah lebih banyak dilakukan secara tidak langsung. Yang dimaksud pengawasan tidak langsung di sini adalah ketua nazhir tidak memantau secara langsung dan berkala kerja dari tiap nazhir wakaf. 3) Masyarakat, Bentuk pengawasan dari masyarakat bersifat sangat sederhana. Mereka hanya melihat perilaku dan akhlak seorang kiai (nazhir wakaf), dan melihat langsung bukti dari pengelolaan harta wakaf yang sudah mereka serahkan ke pesantren. Pihak nazhir wakaf pesantren Al-Hikmah tidak membuat laporan tentang pengelolaan dan penggunaan dana wakaf yang dihimpun kepada masyarakat (wakif). Dalam hal ini sifat transparansi cukup terwakili melalui sifat amanah nazhir dan pimpinan pesantren. 


\section{Wakaf Untuk Pemberdayaan Pendidikan}

Wakaf Pesantren Al-Hikmah semenjak berdirinya menegaskan bahwa seluruh aset pondok adalah wakaf untuk pendidikan. Dengan demikian kontribusi wakaf terhadap pendidikan jelas menyeluruh, mulai dari pembangunan, perawatan dan perluasan pondok sampai penyelenggaraan pendidikan semuanya ditopang oleh wakaf. Awalnya Pimpinan Pondok merasa prihatin melihat kondisi kaum muslim, terutama kalangan pesantren yang menduduki posisi mayoritas tetapi hidupnya terbelakang. Retorika tidak dapat menyelesaikan mana yang lebih dominan antara kebodohan dan kemiskinan dapat menyeret kaum muslim pada posisi kemunduran dan keterbelakangan. Kenyataanya masyarakat miskin (kaum muslim) jumlahnya terus bertambah sehingga pihak Pemerintah tidak sanggup menanganinya. Kendati pihak Pemerintah itu telah melakukan upaya-upaya pengentasan kemiskinan melalui berbagai jalur, tetapi hasilnya tidak tuntas. Pimpinan Pesantren Al-Hikmah sejak awal telah merintis jalan menuju pencerahan melalui upayaupaya pemberdayaan wakaf dalam rangka pencarian sumbersumber dana yang dapat menjamin kelestarian pondok dan mampu menyelenggarakan pendidikan murah.

Pimpinan Pesantren Al-Hikmah sejak awal telah menyadari permasalahan tersebut dan segera mencari jalan pencerahan, yaitu dengan memperluas dan memberdayakan wakaf. Keberhasilan upaya perluasan dan pemberdayaan wakaf hingga YPPP Al-Hikmah tetap survive lebih dari 103 tahun lamanya telah membuktikan peran wakaf dan kontribusinya terhadap pendidikan. Pesantren Al-Hikmah telah berhasil menyelenggarakan pendidikan murah dengan kualitas yang dapat dibanggakan. Alumninya sudah mencapai puluhan ribu dan banyak yang tampil sebagai pemimpin, baik tingkat lokal maupun nasional.

Pimpinan Pesantren Al-Hikmah semenjak awal bertekad untuk menyelenggarakan pendidikan gratis sehingga masyarakat dapat mengikuti pendidikan tanpa mengeluarkan biaya, tetapi kualitasnya tetap terjaga sehingga memiliki daya saing tinggi. Sekarang baru sampai pada tahap memberikan subsidi kepada santri sehingga orang tua mereka mampu membiayai anak-anaknya 
belajar di Pesantren Al-Hikmah. Pesantren Al-Hikmah saat ini baru bisa memberikan sekolah gratis untuk 300 orang santri bila $>$ syart in.

Secara kuantitas kontribusi wakaf Pesantren Al-Hikmah terhadap pendidikan dapat dilihat dari subsidi santri. Dibandingkan dengan besarnya anggaran biaya pondok, maka uang yang dibayarkan santri sangat jauh dari cukup. Untuk memenuhi kebutuhan-kebutuhannya sendiri, ditambah lagi untuk memenuhi kesejahteraan guru dan pembantu pondok, biaya pemeliharaan dan pembangunan sarana dan prasarana, dan sebagainya.

Dengan bantuan dana hasil pengelolaan wakaf secara produktif, maka unit cost yang dibayar oleh santri per tahunnya Rp. 2.556.000. Dengan demikian wakaf yang dikelola secara produktif pada lembaga tersebut telah mampu memberikan subsidi sekitar $100-125 \%$ dari unit cost santri per tahunnya.

Semua kekurangan anggaran santri ini dibiayai oleh pondok tersebut dari hasil wakaf yang dikelola secara mandiri dan produktif. Namun di samping melakukan usaha-usaha yang mandiri dan produktif, pondok juga menerima bantuan-bantuan dari luar yang tidak mengikat, baik masyarakat atau pemerintah (dalam dan luar negeri), dalam bentuk barang atau uang. Hanya saja dibandingkan dengan sumber-sumber dana wakaf produktif tadi, dana yang berasal dari sumbangan hanya bersifat komplementer, sehingga tanpa sumbangan pun, pondok tetap berjalan.

Dengan jumlah santri pada Pesantren Al-Hikmah Sirampog Kabupaten Brebes sekitar 5.000 orang, maka dapat dikalkulasikan bahwa subsidi untuk cost santri dari hasil pengelolaan wakaf secara produktif adalah \pm Rp. 14.220.000.000,- rupiah per tahun $(5.000$ x Rp. 2.844.000). Sehingga hasil wakaf mensubsidi setiap santri sebesar Rp. 237.000,- (dua ratus tiga puluh tujuh ribu rupiah) setiap bulan atau Rp.2.844.000,- (dua juta delapan ratus empat puluh empat ribu rupiah) setiap tahun. Hal ini belum termasuk cost untuk insentif guru, biaya operasional pendidikan, perluasan lahan, biaya pengelolaan harta wakaf, dan sebagainya. 


\section{Pembangunan Sarana dan Prasarana Pendidikan}

Di antara unsur pendidikan yang tidak kalah pentingnya untuk diperhatikan adalah sarana dan prasarana pendidikan. Sering kali proses belajar mengajar terganggu karena fasilitas yang tersedia kurang memadai. Hal tersebut tentu saja berdampak pula pada kegairahan murid dan guru dalam proses belajar mengajarnya.

Untuk merealisasikan tujuan di atas, YPPP Al-Hikmah bukan saja melakukan pembangunan sarana, melainkan juga melakukan pemeliharaan. Setiap tahun pesantren ini menghabiskan dana yang cukup besar, baik untuk pembangunan maupun pemeliharaan sarana yang lain.

Seiring perkembangannya, proyek pembangunan dan pemeliharaan yang menjadi perhatian Pesantren Al-Hikmah, yang dikerjakan oleh bagian ini, meliputi Masjid An-Nur, GOR, Perpustakaan, Musala, Wisma, Asrama santri putra dan putri, Asrama PTQ, Ruang belajar komplek putra dan putri, Laboratorium komputer, IPA dan bahasa, Ruang Workshop Komputer dan warnet, Tata Busana dan Pengelasan, Ruang AVA (Audio Visual), Gedung Koperasi Malhik 2 (M2Mart), Tsania FM dan Pusat Kesehatan Santri dan Masyarakat dan lain sebagainya.

Untuk menjaga kelangsungan kebersihan, kenyamanan lingkungan pesantren, selain membangun pertamanan, pembuatan tempat sampah yang permanen, tata keindahan jalan sekitar lokasi pesantren juga ikut diperhatikan. Sebagian jalan di lingkungan tersebut masih berupa tanah, sehingga pada musim panas debudebu bertebaran, di sisi lain, pada waktu musim hujan, jalan itu menjadi becek. Padahal ada beberapa jalan yang menjadi lalu lintas utama santri ketika menuju kelas. Hal ini tentu mengganggu kenyamanan dan kesehatan. Berdasarkan kebutuhan itu, diadakan paving beberapa jalan dalam kompleks Pondok.

Tak hanya itu untuk menjaga ketertiban Pesantren Al-Hikmah, juga dibangun sarana lain seperti membuat pagar. Namun bukan berarti pagar dibangun untuk meningkatkan keamanan Pesantren. Sebab tanpa pengamanan siskamling pun sebenarnya Pesantren ini sudah aman, yaitu dijaga langsung oleh masyarakat Di samping itu 
juga sarana pembangunan gardu listrik untuk penerangan pesantren juga menjadi perhatian.

\section{Kaderisasi dan Peningkatan SDM}

Pesantren Al-Hikmah dalam suksesi kepemimpinan dilakukan secara geneologis seperti pesantren pada umumnya, tapi meskipun demikian, Pesantren Al-Hikmah meletakkan proses kaderisasi sebagai sesuatu yang sangat penting. Sejarah timbul dan tenggelamnya suatu usaha, terutama hidup dan matinya pesantrenpesantren di tanah air, memberikan pelajaran tentang pentingnya kaderisasi.

Pelaksanaan kaderisasi di Pesantren Al-Hikmah, secara langsung telah dilakukan. Langkah-langkah kaderisasi tersebut mencakup uswah hłasanah, pengarahan, pendekatan, motivasi, penugasan, pembekalan, evaluasi, pembinaan lahir dan batin, yang diberikan secara berjenjang, yakni dari kyai, para pengasuh, pengurus pondok, para ustaz/ustazah, sehingga hasilnya diharapkan mampu terlatih dan teruji bukan hanya lahir tetapi juga batin.

Setelah satu bentuk untuk meneguhkan SDM yang berkualitas sekaligus sebagai sarana untuk lebih mengintegrasikan wawasan keilmuan, pemikiran, dan pengalaman para keluarga inilah, Pesantren Al-Hikmah membantu mekanisme kaderisasi dengan selalu mengirimkan kader-kademya untuk melanjutkan studi, baik di dalam maupun diluar negeri.

\section{Pengelolaan Wakaf Untuk Pemberdayaan Masyarakat}

Manfaat sosial yang disumbangkan pesantren, setidaknya tercermin dalam dua hal, yaitu manfaat langsung dan manfaat tidak langsung (Akbar Zaenuddin, 2002: 113). Manfaat langsung, berupa manfaat yang ditimbulkan pesantren kepada masyarakat disekitar pesantren dalam hal ekonomi dan sosial budaya. Manfaat Tidak Langsung, adalah peranannya dalam manghasilkan lulusan-lulusan santri yang mampu berperan secara strategis dalam pembinaan dan pengembangan masyarakat. Kegiatan pemberdayaan masyarakat 
ini dapat dikelompokkan menjadi empat bidang yaitu bidang ekonomi, bidang kesehatan, bidang sarana dan bidang pendidikan dan keagamaan.

\section{Kesimpulan}

Dalam penelitian ini peneliti menemukan bahwa wakaf bisa bertahan dan berkembang karena faktor kharisma sebagaimana yang diungkap dalam teori Max Weber. Faktor kharisma KH. Masruri Abdul Mughni ini ternyata mampu membuat wakaf bertahan dan berkembang selama ini. Praktik pengelolaan wakaf di YPPP AlHikmah sejak awal dipisahkan dari harta para nazhir dan pengurus pesantren.

Wakaf YPPP Al-Hikmah Sirampog Kabupaten Brebes dikelola secara sinergis dengan pengelolaan pendidikan. Harta wakaf dimaksimalkan fungsi dan hasilnya untuk mendukung kegiatan pendidikan di YPPP Al-Hikmah. Hasil wakaf digunakan untuk menopang operasional pendidikan, baik untuk menyediakan sarana prasarana maupun biaya operasional unit-unit pendidikan.

Praktik-praktik manajemen yang diterapkan YPPP Al-Hikmah, dalam pengelolaan wakafnya masih bersifat tradisional. Pemanfaatan wakaf di YPPP Al-Hikmah Sirampog Kabupaten Brebes antara lain untuk pemberdayaan pendidikan, yaitu sebagai penyangga dana pendidikan. Wakaf Pesantren Al-Hikmah semenjak berdirinya menegaskan bahwa seluruh aset pondok adalah wakaf untuk pendidikan. Pemanfaatan wakaf untuk pemberdayaan masyarakat di YPPP Al-Hikmah Sirampog Kabupaten Brebes direalisasikan melalui kegiatan-kegiatan yang dapat dikelompokkan menjadi empat bidang, yaitu bidang ekonomi, bidang kesehatan, bidang sarana, bidang pendidikan dan keagamaan. Faktor pendukung pengelolaan wakaf di YPPP Al-Hikmah Sirampog Kabupaten Brebes, antara lain: a) Kepercayaan masyarakat yang sangat besar kepada pesantren dan para pengasuhnya, terutama ketokohan KH. Masruri Abdul Mughni dengan segala kharismanya. b) Aset Wakaf YPPP Al-Hikmah seluas $\pm 12,8$ ha dengan status hukum yang kuat. Aset tanah YPPP ALHikmah 95\% sudah bersertifikat wakaf, 4\% sudah memiliki Akta 
Ikrar Wakaf (AIW) dari KUA, 1\% berupa akta jual beli dan lainnya. c) Potensi pasar yang sangat besar dengan jumlah santri mencapai 5000 orang dan frekuensi kunjungan orang tua (wali santri) yang cukup tinggi.

\section{Daftar Pustaka}

Alfian, M. Alfan, 2009. Menjadi Pemimpin Politik, Jakarta: Gramedia Pustaka Utama

Aziz, Moh. Ali, dkk (ed), 2009. Dakwah Pemberdayaan Masyarakat: Paradigma Aksi Metodologi, Yogyakarta: Pustaka pesantren

Billah, M.M., 1986. Pikiran Awal Pengembangan Pesantren dalam M. Dawam Rahardjo (ed) Pergulatan Dunia Pesantren, Jakarta: P3M,

Fanani, Muhyar, 2010. Berwakaf Tak Harus Kaya: Dinamika Pengelolaan Wakaf Uang di Indonesia, Semarang: Walisongo Press

Hasibuan, Malayu S.P., 2014. Manajemen; Dasar, Pengertian, dan Masalah, Jakarta: Penerbit PT Bumi Aksara

Havinal, Veerabhadrappa, 2009. Management and Entrepreneurship, New Delhi: New Age International (P) Limited Publisher

Horikoshi, Hiroko, 1987. Kiai dan Perubahan Sosial, Jakarta: PT. Temprint.

Lovely Professional University (LPU), 2011. Principles and Practices of Management, New Delhi: Excel Books Private Limited

Mahendrawati, Nanih, 2001. Pengembangan Masyarakat Islam, Bandung: PT. Remaja Rosdakarya

Mahfudz, Sahal, 1994. Nuansa Fiqih Sosial, Yogyakarta: LkiS, , Cet. ke-1

Manawi, Muhammad Abdul Rauf Al-, 1972. Faid\} Al-Qadir Syarh\} AlJami` Al-Słaghir, jil. I, Cet. ke-2, Beirut: Dar al-Ma'rifah

Najib, Tuti A., dan Ridwan Al-Makassary (editor), 2006. Wakaf, Tuhan dan Agenda Kemanusiaan Studi tentang Wakaf dalam 
Perspektif Keadilan Sosial di Indonesia, cet. ke-1, Jakarta: CSRC UIN Syarif Hidayatullah.

Olum, Yasin, 2004. Modern Management Theories And Practices, Being a paper presented at the 15th East African Central Banking Course, held on 12th July 2004, at Kenya School of Monetary Studies

Sawai, Jerry Joas, 2005. Pembangunan dalam Perspektif Sosiologi, Semarang: Gunungjati

Setiawan, Iwan, 2012. Dinamika Pemberdayaan Petani: Sebuah Refleksi dan Generalisasi Kasus di Jawa Barat, Bandung: Widya Padjadjaran

Soetomo, 2011. Pemberdayaan Masyarakat: Mungkinkah Muncul Antitesisnya, Yogyakarta: Pustaka Pelajar

Suharto, Edi, 2010. Membangun Masyarakat Memberdayakan Rakyat: Kajian Strategis Pembangunan Kesejahteraan Sosial dan Pekerjaan Sosial, Cet. Ke-4, Bandung: PT. Refika Aditama

Sukamto, 1999. Kepemimpinan Kiai dalam Pesantren, Jakarta: LP3ES

Syarbiniy, Syamsuddin M. Khatib Al-, 1997. Mughi al-Muhtaj Syarh\} al-Minhaj, , Juz II, Beirut: Dar Al-Ma'rifah

Taylor, Frederick Winslow, 1919. The Principles of Scientific Management, New York \& London: Harper \& Brother Publisher

Terry, George R., Leslie W. Rue, 2000. Principles of Management (Dasar-Dasar Manajemen), Terj. G. A. Ticoalu, Jakarta: PT Bumi Aksara

Weber, Max, 1946. From Max Weber: Essays in Sosiology, H. H. Gerth dan C. Wright Mills (Ed), New York: Oxford University Press. 1947, The Theory of Social and Economic Organization, Ed, Parsons, Talcott, New York: Oxford University Press.

Zubaedi, 2007. Pemberdayaan Masyarakat Berbasis Pesantren, Kontribusi Fiqh Sosial Kiai Sahal Mahfudh dalam Perubahan Nilai-Nilai Pesantren, Cet. ke-1, Yogyakarta: Pustaka Pelajar. 